\title{
ADJUSTING THE STRUCTURE COMBINATIONS OF PLANT COMMUNITIES IN URBAN GREENSPACE REDUCED THE MAINTENANCE ENERGY CONSUMPTION AND GHG EMISSIONS
}

\author{
Yang LIU ${ }^{1}$, Qiusheng YANG ${ }^{*}$, Lichao DUAN ${ }^{2}$ \\ ${ }^{1}$ College of Forestry, Henan Agricultural University, 63 Nongye Road, Zheng Zhou, 450002, China \\ ${ }^{2}$ Management Committee of Zheng Dong New District, 22 Business Outer Ring Road, \\ Zheng Zhou, 450008, China
}

Received 23 November 2017; accepted 25 June 2018

\begin{abstract}
Maintaining urban greenspace results in energy use and GHG emissions. To understand the change of the annual maintenance energy consumption and GHG emissions in varying combinations of plant structures (plant density or proportion of area covered) in urban greenspace, this study investigated 34 urban plant communities as sample plots $(20 \times 20 \mathrm{~m})$, and divided them into woodland, shrub, herbaceous and grassland layers. The average energy use and GHG emissions in the woodland layer were $18.64 \mathrm{MJ} /$ tree $/ \mathrm{y}^{-1}$ and $0.23 \mathrm{~kg} / \mathrm{CO}_{2}$-e/tree $/ \mathrm{y}^{-1}$, respectively. In the shrub, herbaceous, and grassland layers, the average energy consumption was $3.73,2.27,7.23 \mathrm{MJ} / \mathrm{m}^{2} / \mathrm{y}^{-1}$, and the average GHG emissions were $0.06,0.02,0.09 \mathrm{~kg} / \mathrm{CO}_{2}-\mathrm{e} / \mathrm{m}^{2} / \mathrm{y}^{-1}$, respectively. The energy use and GHG emission curves had parabolic trends as the plant density in the woodland layer increased and increasing curves with two peaks as the plant area proportions of the shrub, herbaceous, and grassland layers increased. The annual maintenance of urban greenspace can divide into low, average and high levels of energy consumption and GHG emissions due to the change in the plant structure combinations. Furthermore, city managers and landscape designers can refer to the energy consumption and GHG emissions trends to understand the environmental impact of maintenance tasks. The future plant structures in greenspace can be better designed to improve ecosystem services based on limiting the maintenance environmental impacts.
\end{abstract}

Keywords: urban greenspace, plant community maintenance, plant structure combinations, environmental impact, energy consumption, GHG emissions.

\section{Introduction}

Ecosystem services provided by urban greenspace can provide healthy environments and health benefits to the urban residents (Tzoulas et al., 2007). The ecosystem services such as air and water purification, habitat provision, aesthetic and spiritual, noise pollution control, climate and radiation regulation, can protect the health of the ecosystem and improve the physical and psychological health level to individuals (Tzoulas et al., 2007). However, green spaces that are perceived to be overgrown or unmanaged may have a negative effect on peoples' well-being by increasing anxiety caused by fear of crime (Kuo, Bacaicoa, \& Sullivan, 1998; Bixler \& Floyd, 1997). The required maintenance activities in urban greenspaces include grass cutting, tree pruning, litter collection, and weed control (Lindholst, 2008). Maintenance work must be performed for plants in urban greenspace in ways that are suitable for their multifunctional services for both citizens and the city ecology. In addition, the highly artificial resolution of plant communities in urban greenspace requires high labour costs, significant work by machines, and high levels of energy consumption and greenhouse gases (GHG) emissions to perform routine maintenance jobs (Barker \& Prostak, 2009). However, in China, the rapid urbanization process has led the total urban greenspace area to reach 2.67 million ha in 2015, which is twice the 1.32 million ha present in 2005 (Laiyun, Wenbo, \& Weisheng, 2015).

The maintenance of urban greenspace can directly cause energy consumption and GHG emissions (YuanYuan, Genovese, T. A. University, \& T. University, 2016). Most of the plant trimming and water transportation work uses internal combustion engine equipment such as shrub trimmers, push or riding mowers, power chainsaws and vehicles used to transport plant waste. These tools usually consume fossil fuel energy and produce exhaust emissions,

${ }^{*}$ Corresponding author. E-mail: qsyang@henan.edu.cn 
i.e., $\mathrm{NO}_{\mathrm{x}}, \mathrm{CO}$, and $\mathrm{CO}_{2}$ (Khan, Russell, Welch, Cocker III, \& Ghosh, 2012). Irrigation consumes city water, and the machines used for fertilization and pesticide spraying not only use fertilizers, pesticides and fossil fuels but also produce exhaust emissions (West \& Marland, 2002) and release soil carbon (Wang, Wu, Zhou, Chen, \& Wu, 2014). In general, the energy consumption and the GHG emissions can be regarded as major indicators of the environmental impacts of greenspace maintenance (Shu-Hua, 2010). Greenspace maintenance consumes many resources such as fresh water and fossil fuels. In addition, the global warming potential of GHG emissions has already been identified as the most significant environmental problem related to human activities (Fuglestvedt, 2010), and most of the greenspace maintenance procedures have been identified as significant GHG contributors (Ingram, 2012). However, the high resource requirements and the important environmental problems such as carbon emissions are not currently considered in plant maintenance (Lazzerini, Lucchetti, \& Nicese, 2015).

While a variety of studies exist on the environmental impacts of plant nurseries, forest management and agriculture production areas, most of those studies were assessed using the life cycle assessment (LCA) method, which is a methodological framework according to the ISO standard (International Organization for Standardization [ISO], 2006). LCA is widely used to evaluate the environmental impact of a product or production system and is considered an effective approach to defining and quantifying energy consumption and GHG emissions (Casey \& Holden, 2006a, 2006b). In an LCA of the GHG emissions from an ornamental plant nursery in Italy, the results showed that the in-pot nursery system, with an emissions range of 7.444-26.489 $\mathrm{kg}$ of $\mathrm{CO}_{2}$-e, had a much greater impact than in-field production processes (0.607$1.013 \mathrm{~kg}$ of $\mathrm{CO}_{2}$-e) (Lazzerini et al., 2015). An LCA of forest management in Sweden showed that the energy use per $\mathrm{m}^{3}$ timber production was approximately 150-200 MJ and that the GHG emissions ranged from 12459 to 17110 $\mathrm{kg} \mathrm{CO}$-e (Berg \& Lindholm, 2005). A grassland farming analysis in southern Germany based on the LCA method demonstrated that the energy consumption of intensive, extensified and organic grassland farms was 19.1, 8.7 and $5.9 \mathrm{GJ} / \mathrm{ha}$, respectively, and that the GHG emissions were 9.4, 7.0 and $6.3 \mathrm{~kg} / \mathrm{CO}_{2}$-e/ha, respectively (Haas, Wetterich, \& Köpke, 2001). Another LCA assessment of agriculture in the Shanxi province of China showed that the energy consumption of a winter wheat-summer maize rotation system was 19059-21944 MJ/t crop production and the GHG emissions were 2285-2676 $\mathrm{kg} \mathrm{CO}_{2}$-e/t crop production (Xiao-Yu, Xi-Hui, Fa-Qi, Xiao-Qin, \& XiaoGang, 2015).

Furthermore, in the urban greenspace maintenance, producing a stable landscape vision can be regarded as a 'product' (Shu-Hua, 2010), and it is possible to define the annual maintenance work as a 'lifecycle' based on the LCA framework (ISO, 2006), due to the annually repeating characteristic of the routine maintenance work in a mature (more than 10 years since establishment) urban greenspace (Jiang \& Peng, 2003). However, there is little existing supporting research in this area. Jo noticed that the annual maintenance carbon emissions in three cities in Korea were approximately 37.0-264.9t $\mathrm{CO}_{2}$-e/ha, and their annual carbon sequestration ability was only approximately $4.7 \mathrm{t} \mathrm{CO}$-e/ha (Jo, 2002). Therefore, there is a strong need for a study of the environmental influence exerted by urban greenspace maintenance, especially because of the highly artificial characteristics of the maintenance (Yuan-Yuan, 2015).

Plant communities combines urban greenspace (Wang, Yang, \& Zhang, 2016). The different plant communities have various structures, such as particular tree densities and combinations of shrub, herbaceous and grassland areas. By dividing the plant community structure into 4 layers (woodland, shrub, herbaceous and grassland) (Yongchang, 2001), the objective of this study was (a) to assess the trends in variation of the annual maintenance energy consumption and GHG emissions due to changes in the plant structure combinations of the plant communities in the urban greenspace and (b) to predict the levels of maintenance energy use and GHG emissions according to changes in plant structure combinations to understand the environmental impact of maintenance in existing and future urban greenspace. The hypothesis was that within the same greenspace, different combinations of plant structures would have different maintenance requirements, leading to different annual energy costs and GHG emissions. To investigate this hypothesis, we chose 34 plant community sample plots in 4 urban greenspace areas (with a total of $43 \mathrm{ha}$ ). Furthermore, we summarized the density of trees and the shrub, herbaceous and grassland areas through a site survey and a site questionnaire regarding the annual maintenance types and workload by plant layers in each sample plot.

\section{Methods and materials}

\subsection{Study sites}

The investigation was conducted in the region of the Zheng Dong New District, in the northeast part of city Zheng Zhou, Henan province, which is located in the eastern central region of China. The mean annual temperature in the study area is $15.9^{\circ} \mathrm{C}$, and the average annual precipitation is $689.1 \mathrm{~mm}$, characteristic of a typically temperate continental climate with moist soil (Gu, Li, Xing, \& Zhao, 2009; Laiyun et al., 2015). Since the completion of infrastructure construction and plant establishment in 2003, the greenspace in this region has had more than 10 years of stable growth, and the plants have achieved mature growth (Jiang \& Peng, 2003). The green ratio has achieved to $49.1 \%$ in Zheng Dong New District in $2016,8.2 \%$ higher than the average level $(40.9 \%, 2016)$ in Zheng Zhou (Management Committee of Zheng Dong New District, 2017). Figure 1 shows the locations and terrains of the 4 


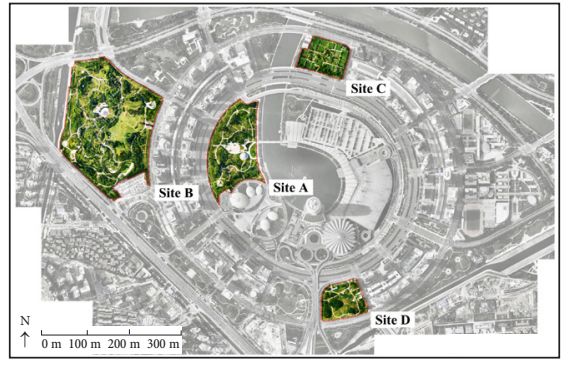

1-1 The locations of study sites



1-2 The terrains elevation of study sites

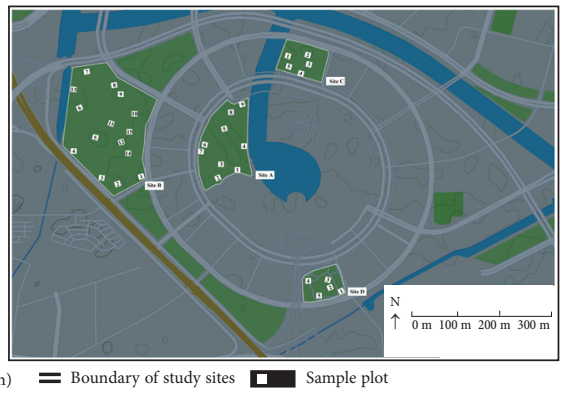

1-3 The locations of sample plots

Figure 1. The locations and terrains of the study sites and sample plots (source: http://www.hntianditu.com/hnmap.aspx)

investigation sites in this study. The sizes of sites A, B, C and $\mathrm{D}$ are 8 ha, 26 ha, 5 ha and 4 ha, respectively (National Geomatics Center of China, 2017). These 4 sites are the major greenspaces in this region, their total size occupied $60 \%$ of the greenspace in Zheng Dong New District. The study sites include park greenspaces (site A \& B), artificial wetland greenspace (site $\mathrm{C}$ ) and roadside greenspace (site D), which represent most urban greenspace types in Zheng Zhou. Each study site had an independent maintenance team. Each team had one site manager; several direct site staff for the daily irrigation and fertilization work, generally allotting one $3000 \mathrm{~m}^{2}$ area for each staff member, one trimming squad for plant pruning and mowing work; one pesticide squad; and one plant waste recycling squad. Table 1 shows the surrounding air quality change $\left(\mathrm{CO}_{2}\right.$ Concentration in $\left.\mathrm{ppm}\right)$ of 1 hour continuously operating of the site maintenance equipment in Zheng Dong area (Tasted in sample plot B15). The data can directly prove GHG emissions discharged by maintenance tasks.

Table 1 . The air quality change of the maintenance equipment operating

\begin{tabular}{|c|c|c|c|c|c|}
\hline \multirow[b]{2}{*}{ Equipment } & \multirow{2}{*}{$\begin{array}{c}\text { Energy } \\
\text { type }\end{array}$} & \multirow{2}{*}{$\begin{array}{l}\text { Ope- } \\
\text { rating } \\
\text { time } \\
\text { (hour) }\end{array}$} & \multicolumn{3}{|c|}{$\mathrm{CO}_{2}$ concentration $(\mathrm{ppm})$} \\
\hline & & & $\underset{\text { range }^{* 1}}{1 \mathrm{~m}}$ & $\begin{array}{l}5 \mathrm{~m} \\
\text { range }^{* 1}\end{array}$ & $\begin{array}{l}10 \mathrm{~m} \\
\text { range }^{* 1}\end{array}$ \\
\hline Shrub & 101 & 1 & 7052.5 & 427.5 & 371.0 \\
\hline Push & trol & & 7128.3 & 624.6 & 71.6 \\
\hline Riding & etrol & 1 & 513.7 & 2493.1 & 86. \\
\hline $3 \mathrm{~m}^{3}-\mathrm{lo}$ & $\operatorname{trc}$ & 1 & 6409.0 & 3217.8 & 422 \\
\hline $\begin{array}{l}5 \mathrm{~m}^{3} \text {-load light } \\
\text { duty vehicle }\end{array}$ & Dieset & 1 & 64 & $=$ & 48 \\
\hline
\end{tabular}

Note: ${ }^{* 1}$ - the distance in straight behind the exhaust pipe of maintenance equipment.

\subsection{Sampling and measurement}

There were total of 34 sample plots chosen in the study sites (Figure 2). The number of sample plots allotted to sites $A, B, C$ and D were $9,15,5$ and 5 , respectively. The size of each plot was $20 \times 20 \mathrm{~m}$, and every plot represented an independent plant community. The number of sample plots chosen at each site followed the classic outdoor plant community research method, which is to look at the change in plant species and the point at which the plant species curve transitions from a dramatic increase to a stable rise indicates the acceptable number of samples (Yongchang, 2001).

In the sample plots, we first divided the plant community into 4 layers, woodland, shrub, herbaceous and grassland (Yongchang, 2001). Then, we investigated the plant quantities in the woodland layer and the plant areas in the shrub, herbaceous and grassland layers. Next, we calculated the plant density in the woodland layer and the area proportions in the shrub, herbaceous and grassland layers. In addition, we administered a questionnaire to the site maintenance teams, asking about the annual (from 06/2016 to 07/2017) maintenance work types and the work frequency and workload of each plant layer in every plot, including mowing/pruning, irrigation, fertilization, pesticide spraying, and plant waste recycling and transportation (Jo, 2002). In addition, we tested the work efficiency, energy consumption and exhaust emissions of the site equipment (Table 2). The energy consumption test abided by regulation GB/T 6072.1-2008 (Standardization Administration of the People's Republic of China, 2008), and the exhaust emission test followed the field test

Table 2. The working efficiency, energy consumption \& GHG emissions of the site equipment

\begin{tabular}{|l|c|c|c|c|}
\hline Equipment & $\begin{array}{c}\text { Energy } \\
\text { type }\end{array}$ & $\begin{array}{c}\text { Working } \\
\text { efficiency }\end{array}$ & $\begin{array}{c}\text { Energy } \\
\text { consump- } \\
\text { tion L/h }\end{array}$ & $\begin{array}{c}\mathrm{GHG} \\
\mathrm{emission} \\
\mathrm{kg} / \mathrm{CO}_{2} \text {-e }\end{array}$ \\
\hline $\begin{array}{l}\text { Shrub } \\
\text { trimmer }\end{array}$ & Petrol & $300 \mathrm{~m}^{2} / \mathrm{h}$ & 0.8 & 1.69 \\
\hline $\begin{array}{l}\text { Push } \\
\text { mower }\end{array}$ & Petrol & $300 \mathrm{~m}^{2} / \mathrm{h}$ & 2.0 & 1.80 \\
\hline $\begin{array}{l}\text { Riding } \\
\text { mower }\end{array}$ & Petrol & $2000 \mathrm{~m}^{2} / \mathrm{h}$ & 3.2 & 2.68 \\
\hline $\begin{array}{l}3 \mathrm{~m}^{3} \text {-load } \\
\text { waste } \\
\text { vehicle }\end{array}$ & Petrol & $20 \mathrm{~km} / \mathrm{h}$ & 1.4 & 3.43 \\
\hline $\begin{array}{l}5 \mathrm{~m}^{3} \text {-load } \\
\text { light duty } \\
\text { vehicle }\end{array}$ & Diesel & $20 \mathrm{~km} / \mathrm{h}$ & 3.0 & 6.20 \\
\hline
\end{tabular}



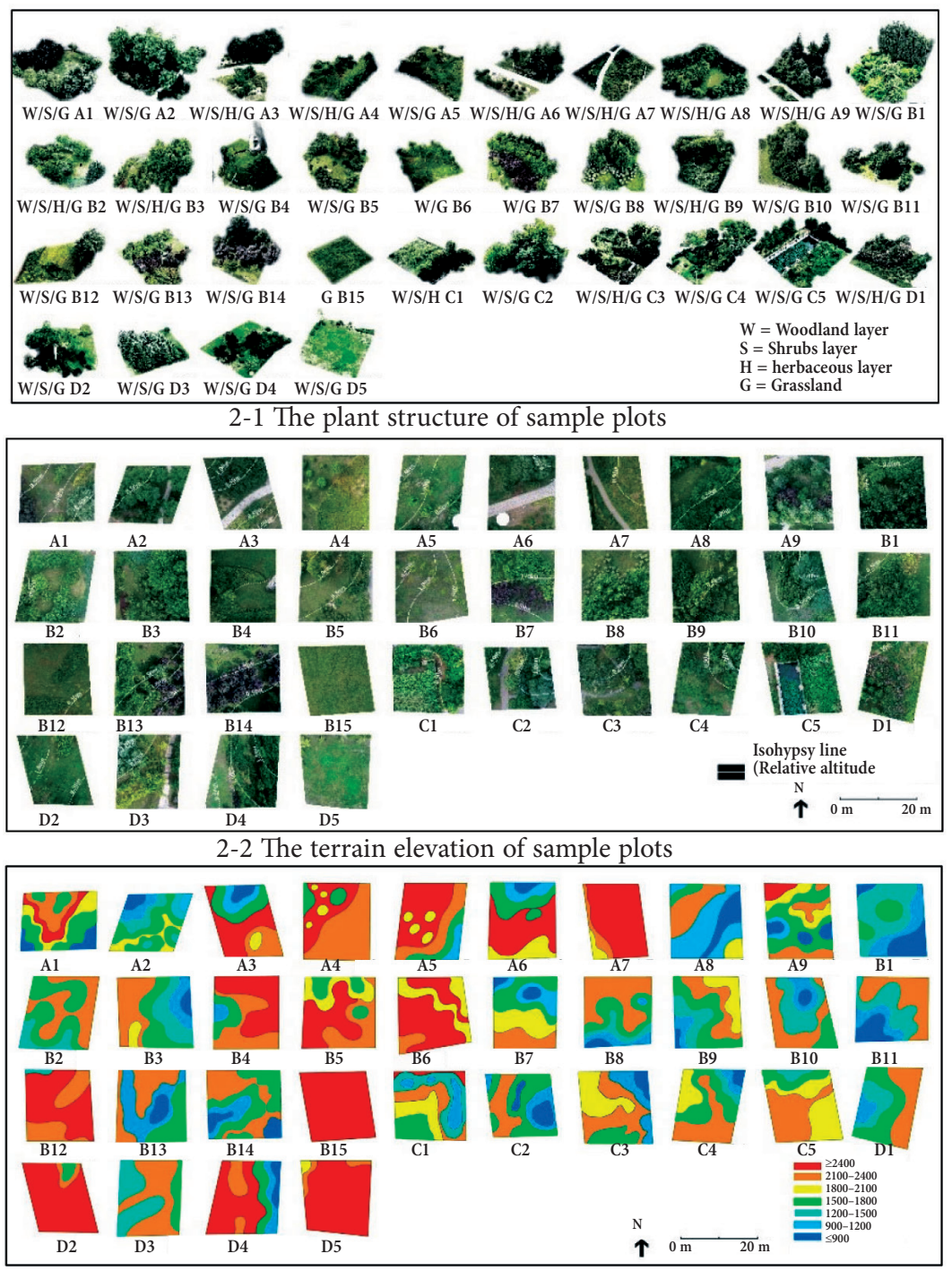

2-3 The insolation hours of sample plots

Figure 2. The graphically illustrate of sample plots (source: http://zzqx.gov.cn/farming/0ZTDofMGN58MGGlSVMGLJbC3m.jhtml)

Table 3. The energy and GHG coefficient of the maintenance materials

\begin{tabular}{|c|c|c|c|c|c|}
\hline Particulars & Unit & $\begin{array}{l}\left(\alpha_{e i}\right) \text { Energy } \\
\text { coefficient } \\
\left(\mathrm{MJ} / \text { unit }^{-1}\right)\end{array}$ & Reference $\left(\alpha_{e i}\right)$ & $\begin{array}{c}\left(\alpha_{c i}\right) \mathrm{GHG} \\
\text { coefficient } \\
\left(\mathrm{kg} \mathrm{CO}_{2} \text {-e/unit }{ }^{-1}\right)\end{array}$ & Reference $\left(\alpha_{c i}\right)$ \\
\hline Petrol & $\mathrm{L}$ & 46.3 & $\begin{array}{l}\text { (Mobtaker, Keyhani, Mohammadi, Rafiee, \& } \\
\text { Akram, 2010) }\end{array}$ & $0 * 3$ & - \\
\hline Diesel & $\mathrm{L}$ & 47.8 & (Yadav, 2014) & $0 * 3$ & - \\
\hline $\begin{array}{l}\text { Irrigation } \\
\text { water }\end{array}$ & $\mathrm{m}^{3}$ & 1.02 & (Rafiee, Mousavi Avval, \& Mohammadi, 2010) & $0^{* 3}$ & - \\
\hline Fertilizer & $\mathrm{kg}$ & $80.08^{* 1}$ & $\begin{array}{l}\text { (West \& Marland, 2002), (Mohammadshirazi, } \\
\text { Akram, Rafiee, Avval, \& Kalhor, 2012; West \& } \\
\text { Marland, 2002) }\end{array}$ & $1.50^{\star 3,{ }^{\star} 4}$ & $\begin{array}{l}\text { (West \& Marland, 2002; } \\
\text { Yang, Zhi, Tingning, \& } \\
\text { Shuibao, 2015) }\end{array}$ \\
\hline Pesticide & $\mathrm{kg}$ & $143^{* 2}$ & (Singh \& Mittal, 1992; West \& Marland, 2002) & $0.35^{* 3,{ }^{*} 5}$ & (West \& Marland, 2002) \\
\hline
\end{tabular}

Note: ${ }^{*} 1$ - Includes $1.98 \mathrm{MJ} /$ unit for site transportation and $78.1 \mathrm{MJ} /$ unit for the fertilizer's thermal energy conversion coefficient;

${ }^{\star 2}$ - Includes $23 \mathrm{MJ} /$ unit for site transportation and $120 \mathrm{MJ} /$ unit for the pesticide's thermal energy conversion coefficient; ${ }^{{ }^{*}}$ - Not traced back to the upstream procedure GHG emissions. The GHG emissions from the production and the transportation of the particulars were not included in this study; ${ }^{*} 4$ - Includes the fertilizer site transportation and site-leached GHGs, $0.04 \mathrm{~kg} \mathrm{CO}$-e/unit-1 for site transportation and $1.46 \mathrm{~kg} \mathrm{CO}_{2}$-e/unit-1 for site leaching; ${ }^{{ }^{5}}$ - Includes the pesticide site transportation and the GHG emissions of the spray machine. 


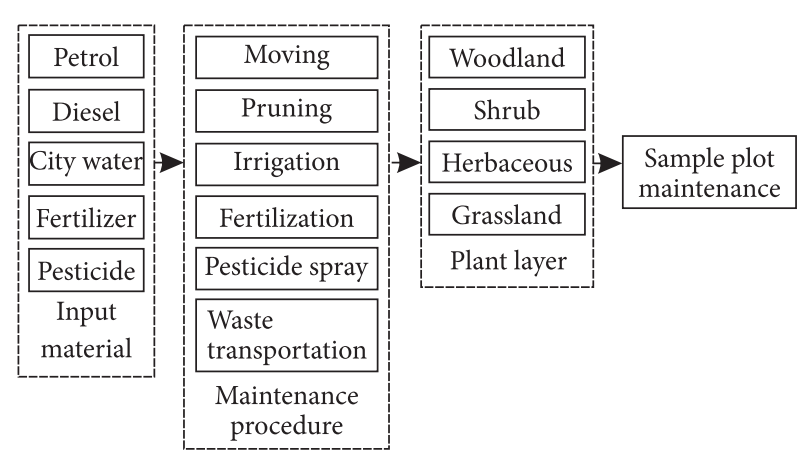

Figure 3. The lifecycle flow chart of the sample plot maintenance

procedure of the GB/T 8190.2-2011 regulation (Standardization Administration of the People's Republic of China, 2011). Next, the annual ranges of on-site energy consumption $(\mathrm{MJ})$ and $\mathrm{GHG}$ emissions $\left(\mathrm{kg} / \mathrm{CO}_{2}\right.$-eq) of each plant layer in every sample plot were calculated. Then, we summarized the trends in variation of the maintenance energy costs and GHG emissions as tree density and area compositions of the shrub, herbaceous and the grassland layers changed. All data were calculated and analysed in Excel 2016. Table 3 shows the coefficient of the site maintenance materials input in equivalent energy units of $\mathrm{MJ}$ and the GHG emissions in units equivalent to $\mathrm{CO}_{2}$ emissions of $\mathrm{kg} / \mathrm{CO}_{2}$-e.

The lifecycle range in this study was one maintenance year (from 06/2016 to 07/2017), and the system boundary was only within the on-site working stage. The energy consumption and GHG emissions from the upstream procedures (i.e., the production, transportation and market selling) of the fossil fuels, fertilizer, pesticide and site machines were not included. The system also neglected the energy use and carbon emissions from labour. The sample plots' maintenance lifecycle flow chart is shown in Figure 3, and their energy consumption and the GHG emissions divided by plant layers were calculated by formula (1)-(3).

$$
E C_{l}=\sum_{i}^{n} \alpha_{e i} \times A_{w i}
$$

where $E C_{l}$ is the energy consumption (MJ) in one plant layer of a sample plot; and $\alpha_{e i}$ represents the energy coefficient of the input material; $i$. $A_{w i}$ denotes the lifecycle amount of input material; $i$ - used in one plant layer of a sample plot. The lifecycle consumption data for each energy material came from the site questionnaire survey.

The $A_{w i}$ of petrol and diesel use related to the maintenance procedures of mowing, pruning and waste transportation was calculated with the following equation:

$$
A_{w i}=\sum_{a}^{n} \frac{M_{w a}}{E_{e a}} \times c_{a},
$$

where $M_{w a}$ denotes the lifecycle workload of the maintenance equipment; $a$ - related to the use of the input material; $i$ - in one plant layer of a sample plot; $E_{e a}$ and $c_{a}$ represent the working efficiency and the fuel consumption of the maintenance equipment, respectively.

The calculation method for the GHGs emitted by over the lifecycle by the maintenance input material consumed by one plant layer in a sample plot, represented as $G_{e}$, was:

$$
G_{e}=\sum_{i}^{n} \alpha_{c i} \times A_{w i}+\sum_{a}^{n} \frac{M_{w a}}{E_{e a}} \times g_{a},
$$

where $\alpha_{c i}$ represents the GHG coefficient of the input material, $i$. The hourly GHG emissions of the maintenance machines; $a$ - related to the use of the input material; $i-$ in one plant layer in a sample plot is represented by $g_{a}$.

\section{Results}

\subsection{Changes in plant structure combinations and the maintenance workload}

Figures 4-7 are sample plots showing the trends in annual maintenance workload (from 06/2016 to 07/2017) with changing tree density in the woodland and proportions of the area in the shrub, herbaceous, and grassland layers. The prediction equations for the maintenance workload in the figures above were calculated by plant layers. In every plant layer in the plot, data collected about the maintenance work was divided into four parts: mowing/ pruning and plant waste transportation, irrigation, fertilization, and pesticide spraying. Most herbaceous plants in the study areas, such as Ophiopogon japonicus and Fastsia japonica, require very little trimming for routine maintenance, so their contribution to the pruning and waste transportation workload were neglected in this study.

In general, most of the figures reflected the tendency of the maintenance workload to increase as the tree density or the proportion of the area covered by the shrub, herbaceous, and grassland layers increased. Two exceptions were waste transportation and pesticide spraying in the maintenance of woodland (Figure 4a and Figure $4 \mathrm{~d}$ ). When the tree density increases to a forest scale, the ground plant matter will usually leave the area naturally, thereby reducing the maintenance workload. Furthermore, after the calculating the regression of the prediction equation, the overall $R^{2}$ was greater than 0.5 , $p<0.05$.

\subsection{The overall maintenance energy consumption and GHG emissions of the study areas}

Based on the above prediction equations of the maintenance workload and the plant structure combinations in the sample plots (Figures 4-7), the lifecycle maintenance energy consumption and the GHG emissions in each plant layer in the plots was calculated through formula (1)-(3). Tables 4 and 5 show the minimum, maximum, and average on-site energy consumption and GHG emissions for the different types of maintenance work by plant layers. The energy consumption and GHG 


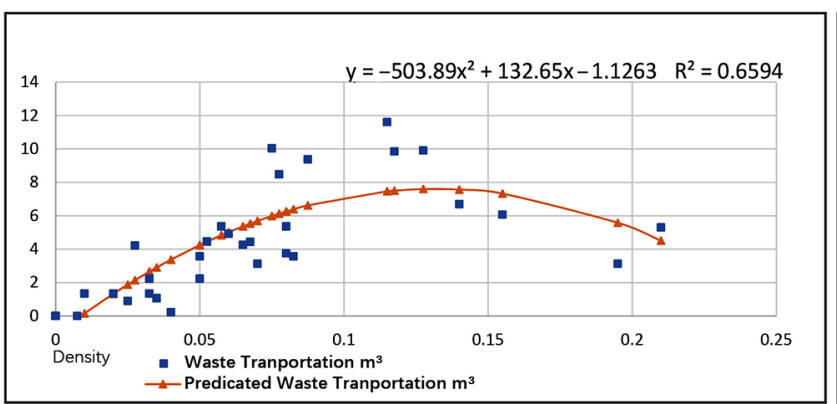

a)

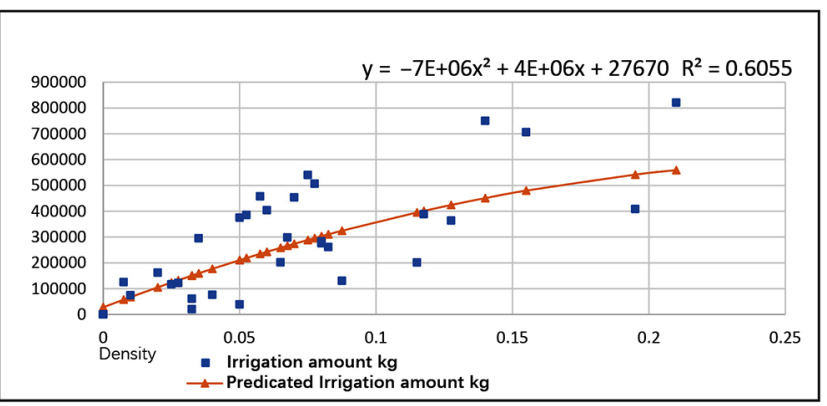

b)
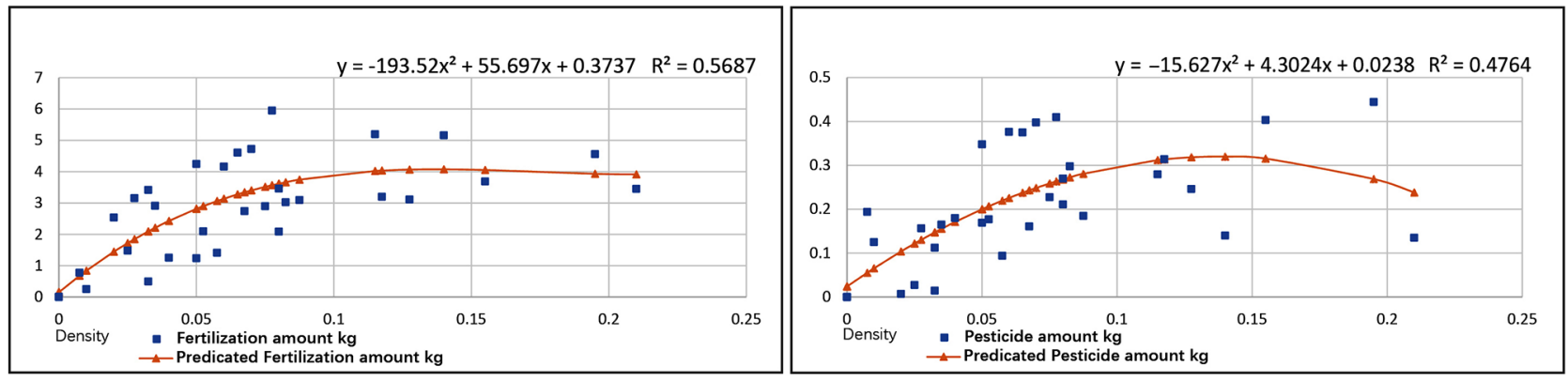

c)

Figure 4 . The woodland maintenance workload with different tree densities

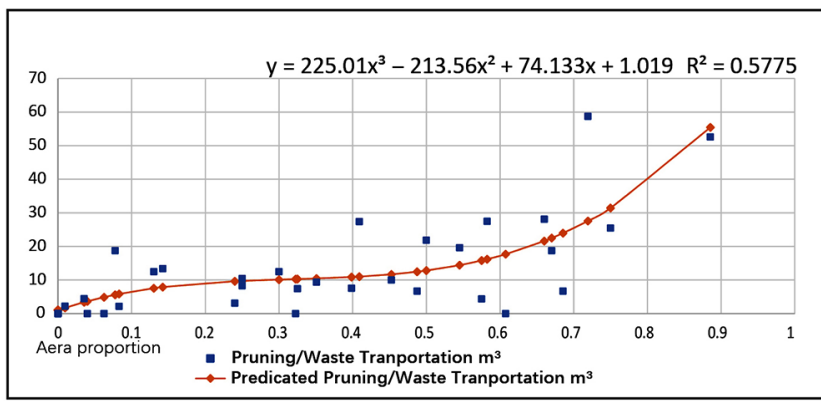

a)



c)

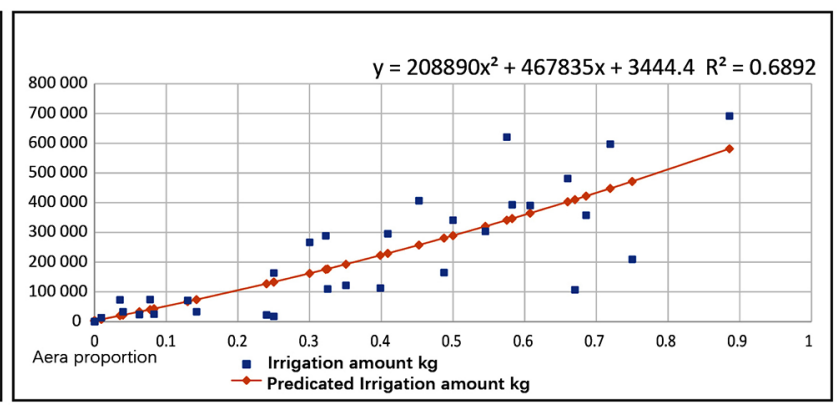

b)

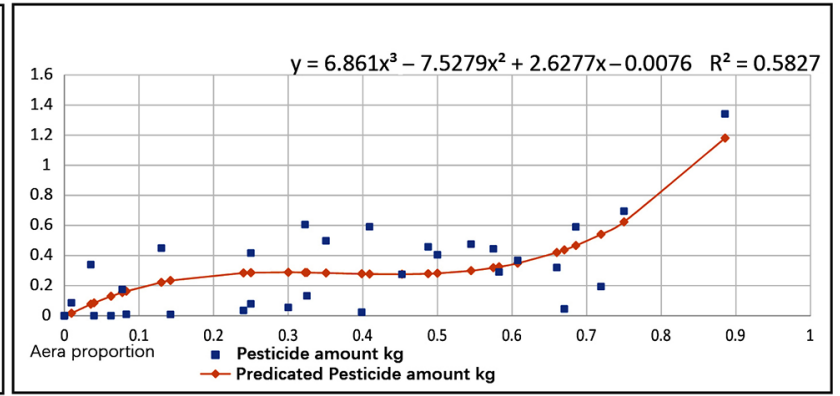

d)

Figure 5. The shrub maintenance workload with different shrub proportions of the area

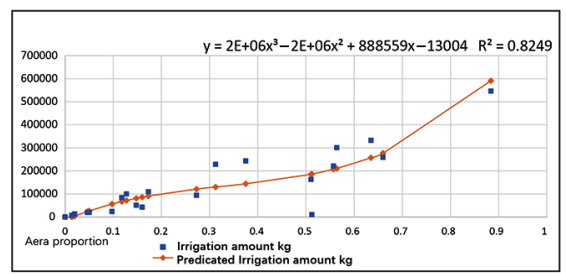

a)



b)



c)

Figure 6. The herbaceous maintenance workload with different herbaceous proportions of the area 




a)

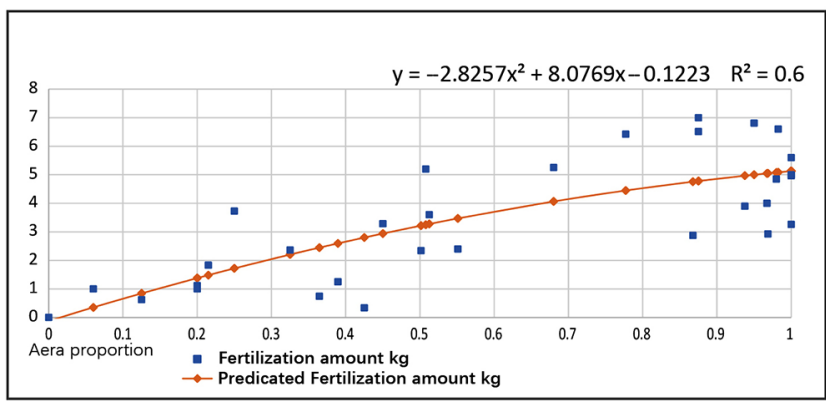

c)

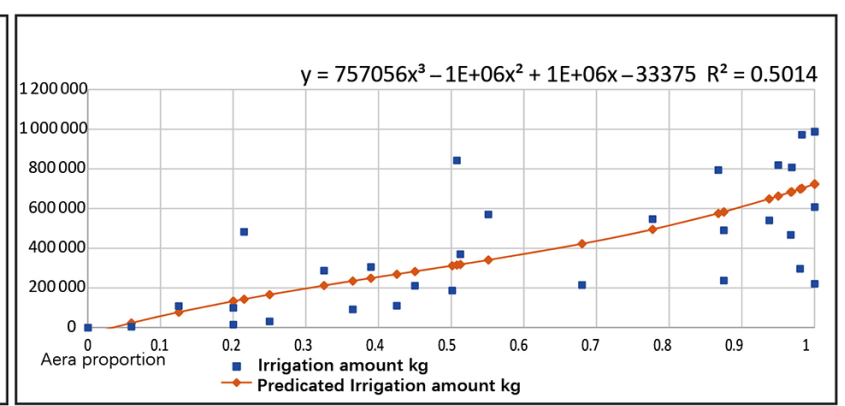

b)

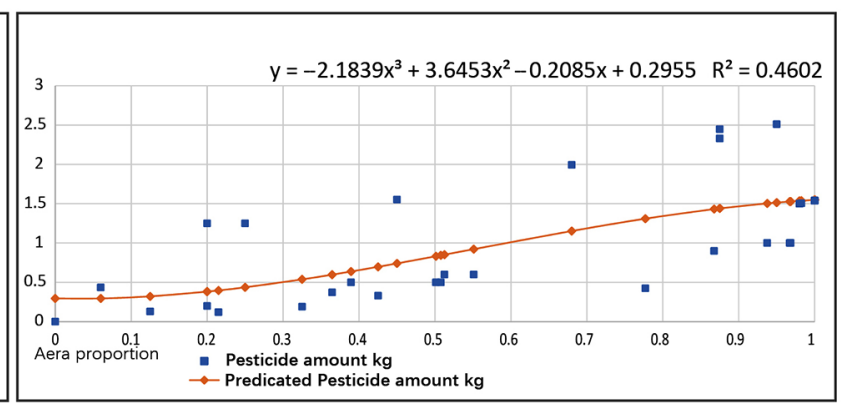

d)

Figure 7. The grassland maintenance workload with different grassland proportions of the area

emissions are presented per plant in the woodland and per $\mathrm{m}^{2}$ in the shrub, herbaceous, and grassland layers, over a one-year lifecycle.

In Table 4, during the one-year lifecycle, irrigation consumed the most significant amount of energy in the woodland, shrub, and herbaceous layers $\left(9.24 \mathrm{MJ} / \mathrm{tree}^{-1} \mathrm{y}^{-1}\right.$, 1.48 and $1.12 \mathrm{MJ} / \mathrm{m}^{2} / \mathrm{y}^{-1}$, respectively) and mowing consumed the most energy in the grassland layer $\left(3.64 \mathrm{MJ} / \mathrm{m}^{2}\right.$ / $\mathrm{y}^{-1}$ ). In addition, pesticide spraying in the shrub and the herbaceous layers had the lowest energy costs, with 0.33 and $0.11 \mathrm{MJ} / \mathrm{m}^{2} / \mathrm{y}^{-1}$, respectively. Waste transportation in the woodland and grassland layers accounted for the next lowest levels of energy consumption, with $0.85 \mathrm{MJ} / \mathrm{tree}^{-1} \mathrm{y}^{-1}$ and $0.21 \mathrm{MJ} / \mathrm{m}^{2} / \mathrm{y}^{-1}$, respectively.

As shown in Table 5, within the plant maintenance lifecycle range of this study, pesticide spraying discharged the least GHG emissions in all plant layers, contributing only approximately $1.3 \%-2 \%$ of the total GHG emissions in each plant layer. However, in the woodland and herbaceous layers, fertilization contributed the most significant GHG emissions, $0.18 \mathrm{~kg} / \mathrm{CO}_{2}-\mathrm{e} /$ tree $/ \mathrm{y}^{-1}$ and $0.02 \mathrm{~kg} / \mathrm{CO}_{2}$ $\mathrm{e} / \mathrm{m}^{2} / \mathrm{y}^{-1}$, respectively. In addition, the significant $\mathrm{GHG}$

Table 4. The lifecycle maintenance energy consumption in the sample plots

\begin{tabular}{|c|c|c|c|c|}
\hline Plant layer & Maintenance work & $\begin{array}{c}\text { Min. Energy consumption } \\
\left(\mathrm{MJ} / \text { tree } / \mathrm{y}^{-1}\right)\end{array}$ & $\begin{array}{c}\text { Max. Energy consumption } \\
\left(\mathrm{MJ} / \text { tree } / \mathrm{y}^{-1}\right)\end{array}$ & $\begin{array}{c}\text { Avg. Energy consumption } \\
\left(\mathrm{MJ} / \text { tree } / \mathrm{y}^{-1}\right)\end{array}$ \\
\hline \multirow{6}{*}{ Woodland } & Pruning & $-{ }^{\star} 1$ & $-^{* 1}$ & $-{ }^{\star} 1$ \\
\hline & Irrigation & 3.24 & 19.47 & 9.24 \\
\hline & Fertilization & $0^{* 2}$ & 20.32 & 7.68 \\
\hline & Pesticide spraying & $0^{* 2}$ & 2.21 & 0.87 \\
\hline & Waste transportation & $0^{* 2}$ & 1.37 & 0.85 \\
\hline & Total & 3.24 & 43.37 & 18.64 \\
\hline Plant layer & Maintenance work & $\begin{array}{l}\text { Min. Energy consumption } \\
\left(\mathrm{MJ} / \mathrm{m}^{2} / \mathrm{y}^{-1}\right)\end{array}$ & $\begin{array}{l}\text { Max. Energy consumption } \\
\left(\mathrm{MJ} / \mathrm{m}^{2} / \mathrm{y}^{-1}\right)\end{array}$ & $\begin{array}{l}\text { Avg. Energy consumption } \\
\left(\mathrm{MJ} / \mathrm{m}^{2} / \mathrm{y}^{-1}\right)\end{array}$ \\
\hline \multirow{6}{*}{ Shrub } & Pruning & 0.11 & 0.11 & 0.11 \\
\hline & Irrigation & 1.33 & 2.12 & 1.48 \\
\hline & Fertilization & 1.04 & 3.34 & 1.21 \\
\hline & Pesticide spraying & 0.16 & 0.65 & 0.33 \\
\hline & Waste transportation & 0.32 & 2.28 & 0.61 \\
\hline & Total & 2.97 & 8.49 & 3.73 \\
\hline
\end{tabular}


End of Table 4

\begin{tabular}{|c|c|c|c|c|}
\hline Plant layer & Maintenance work & $\begin{array}{l}\text { Min. Energy consumption } \\
\left(\mathrm{MJ} / \mathrm{m}^{2} / \mathrm{y}^{-1}\right)\end{array}$ & $\begin{array}{l}\text { Max. Energy consumption } \\
\left(\mathrm{MJ} / \mathrm{m}^{2} / \mathrm{y}^{-1}\right)\end{array}$ & $\begin{array}{l}\text { Avg. Energy consumption } \\
\left(\mathrm{MJ} / \mathrm{m}^{2} / \mathrm{y}^{-1}\right)\end{array}$ \\
\hline \multirow{6}{*}{ Herbaceous } & Trimming & $-{ }^{*} 1$ & $-{ }^{*} 1$ & $-{ }^{*} 1$ \\
\hline & Irrigation & $0^{\star 2}$ & 1.71 & 1.12 \\
\hline & Fertilization & 0.62 & 1.48 & 1.04 \\
\hline & Pesticide spraying & 0.02 & 0.14 & 0.11 \\
\hline & Waste transportation & $-{ }^{*} 1$ & $-{ }^{*} 1$ & $-{ }^{* 1}$ \\
\hline & Total & 0.65 & 3.32 & 2.27 \\
\hline \multirow{6}{*}{ Grassland } & Mowing & 2.46 & 8.84 & 3.64 \\
\hline & Irrigation & 0.99 & 1.85 & 1.68 \\
\hline & Fertilization & 1 & 1.35 & 1.16 \\
\hline & Pesticide spraying & 0.46 & 1.48 & 0.54 \\
\hline & Waste transportation & 0.14 & 0.51 & 0.21 \\
\hline & Total & 5.05 & 14.02 & 7.23 \\
\hline
\end{tabular}

Note: ${ }^{*}$ - There was no related energy cost for these types of plant maintenance; ${ }^{*}$ - There was no maintenance material input in these types of plant maintenance.

Table 5. The lifecycle maintenance GHG emissions in the sample plots

\begin{tabular}{|c|c|c|c|c|}
\hline Plant layer & Maintenance work & $\begin{array}{l}\text { Min. GHG emission } \\
\left(\mathrm{kg} / \mathrm{CO}_{2}-\mathrm{e} / \text { tree }^{-} \mathrm{y}^{-1}\right)\end{array}$ & $\begin{array}{l}\text { Max. GHG emission } \\
\left(\mathrm{kg} / \mathrm{CO}_{2}-\mathrm{e} / \text { tree } / \mathrm{y}^{-1}\right)\end{array}$ & $\begin{array}{l}\text { Avg. GHG emission } \\
\left(\mathrm{kg} / \mathrm{CO}_{2} \text {-e } / \text { tree } / \mathrm{y}^{-1}\right)\end{array}$ \\
\hline \multirow{6}{*}{ Woodland } & Pruning & $0^{\star} 1$ & $0^{* 1}$ & $0^{* 1}$ \\
\hline & Irrigation & $0^{\star} 1$ & $0^{\star} 1$ & $0^{* 1}$ \\
\hline & Fertilization & 0.05 & 0.39 & 0.18 \\
\hline & Pesticide spraying & 0.001 & 0.006 & 0.003 \\
\hline & Waste transportation & $0^{\star 1}$ & 0.06 & 0.05 \\
\hline & Total & 0.05 & 0.46 & 0.23 \\
\hline Plant layer & Maintenance work & $\begin{array}{l}\text { Min. GHG emission } \\
\left(\mathrm{kg} / \mathrm{CO}_{2}-\mathrm{e} / \mathrm{m}^{2} / \mathrm{y}^{-1}\right)\end{array}$ & $\begin{array}{l}\text { Max. GHG emission } \\
\left(\mathrm{kg} / \mathrm{CO}_{2}-\mathrm{e} / \mathrm{m}^{2} / \mathrm{y}^{-1}\right)\end{array}$ & $\begin{array}{l}\text { Avg. GHG emission } \\
\left(\mathrm{kg} / \mathrm{CO}_{2}-\mathrm{e} / \mathrm{m}^{2} / \mathrm{y}^{-1}\right)\end{array}$ \\
\hline \multirow{6}{*}{ Shrubs } & Pruning & 0.01 & 0.01 & 0.01 \\
\hline & Irrigation & $0^{* 1}$ & $0^{* 1}$ & $0^{* 1}$ \\
\hline & Fertilization & 0.02 & 0.06 & 0.02 \\
\hline & Pesticide spraying & $0^{\star} 1$ & 0.002 & 0.001 \\
\hline & Waste transportation & 0.02 & 0.12 & 0.03 \\
\hline & Total & 0.04 & 0.19 & 0.06 \\
\hline \multirow{6}{*}{ Herbaceous } & Trimming & $-{ }^{\star 2}$ & $-{ }^{* 2}$ & $-{ }^{* 2}$ \\
\hline & Irrigation & $0^{\star} 1$ & $0^{\star} 1$ & $0^{* 1}$ \\
\hline & Fertilization & 0.01 & 0.03 & 0.02 \\
\hline & Pesticide spraying & 0.0001 & 0.0005 & 0.0004 \\
\hline & Waste transportation & $-{ }^{\star 2}$ & $-{ }^{\star 2}$ & $-{ }^{\star 2}$ \\
\hline & Total & 0.01 & 0.03 & 0.02 \\
\hline \multirow{6}{*}{ Grassland } & Mowing & 0.04 & 0.13 & 0.05 \\
\hline & Irrigation & $0^{* 1}$ & $0^{* 1}$ & $0^{* 1}$ \\
\hline & \begin{tabular}{|l|} 
Fertilization \\
\end{tabular} & 0.02 & 0.03 & 0.02 \\
\hline & Pesticide spraying & 0.001 & 0.004 & 0.002 \\
\hline & Waste transportation & 0.01 & 0.03 & 0.01 \\
\hline & Total & 0.06 & 0.19 & 0.09 \\
\hline
\end{tabular}

Note: ${ }^{*}$ - There were no GHG emissions from these types of plant maintenance; ${ }^{*}-$ There was no related maintenance work in this plant layer. 
emissions contributors in the shrub and the grassland layers were waste transportation and mowing, which discharged $0.03 \mathrm{~kg} / \mathrm{CO}_{2}-\mathrm{e} / \mathrm{m}^{2} / \mathrm{y}^{-1}$ and $0.05 \mathrm{~kg} / \mathrm{CO}_{2}-\mathrm{e} / \mathrm{m}^{2} / \mathrm{y}^{-1}$, respectively.

Overall, the herbaceous layer contributed the least to both average energy consumption and GHG emissions throughout the lifecycle maintenance of the shrub, herbaceous, and grassland layers. Additionally, among the types of plant maintenance work, irrigation was the primary contributor to energy consumption, representing $50 \%, 40 \%, 50 \%$ and $23 \%$ of the total energy cost in the woodland, shrub, herbaceous and grassland layers, respectively. Moreover, the majority of GHG emissions in the woodland and herbaceous layers were contributed by fertilization (78\% and $100 \%$ of their total GHG emissions, respectively). In the shrub layer, the main source of GHG emissions was waste transportation, which contributed $50 \%$ of the shrub layer's GHG emissions; in the grassland layer, the main source of GHG emissions was mowing, which contributed $56 \%$ of the GHG emissions.

\subsection{The maintenance energy and GHG variation trends in the plant layers}

Based on the prediction equations in Figures 4-7, Figures 8-11 show the trends in maintenance energy consumption and GHG emissions based on changes in plant quantities (density of trees and the proportions of area in the shrub, herbaceous, and grassland layers) in the different plant layers in the sample plots.

In general, analysis of the annual maintenance of different plant layers in the sample plots first shows that the variations in energy consumption and GHG emissions displayed a uniform tendency, meaning that as the amount of energy consumed increased, the GHG emissions from the maintenance of the plant layer also increased. Second, there were two trends displayed by the energy consumption and GHG emissions as the plant quantities (the density or the proportion of the area) increased: (a) a parabolic curve where the energy consumption or the GHG emissions (Y-axis) increased as the tree density (X-axis)



a)

Figure 8. The variation trends of maintenance energy consumption \& GHG emissions in the woodland layer of the sample

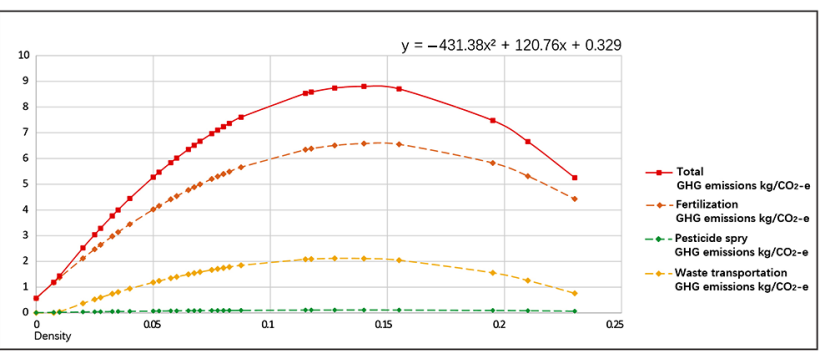

b)



a)



b)

Figure 9. The variation trends of maintenance energy consumption \& GHG emissions in the shrub layer of the sample plots

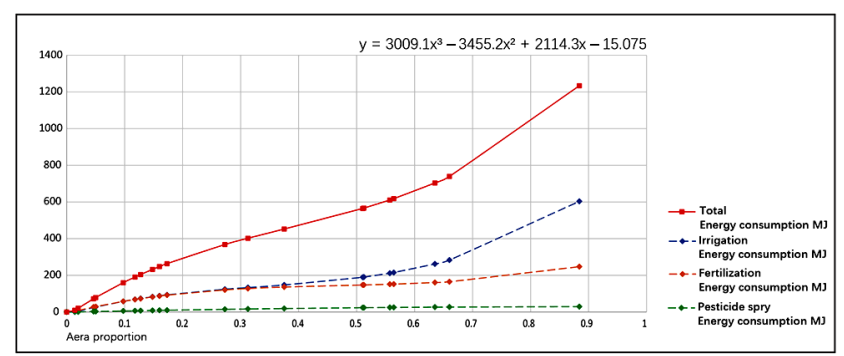

a)

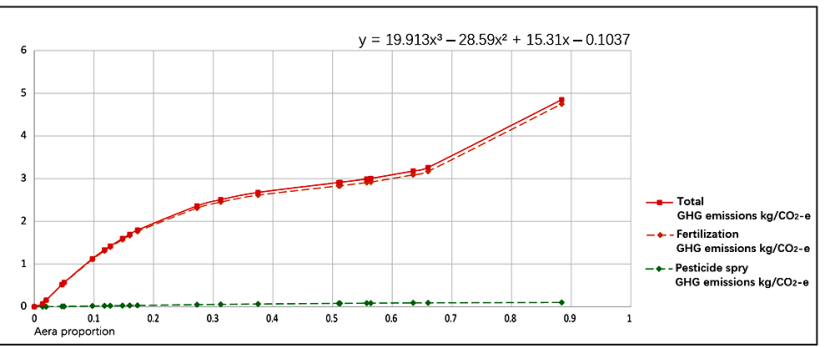

b)

Figure 10. The variation trends of maintenance energy consumption \& GHG emissions in the herbaceous layer of the sample plots 


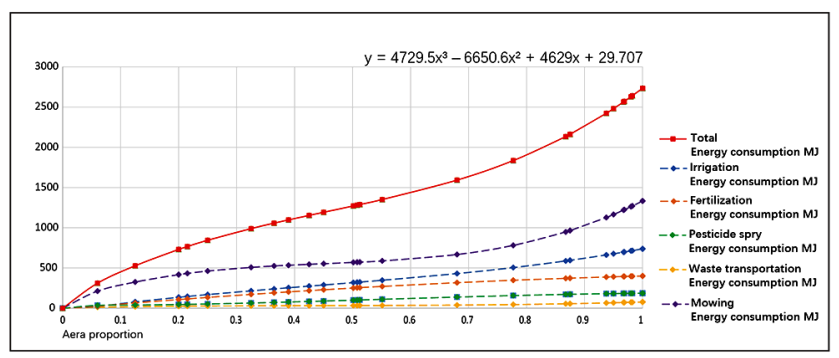

a)

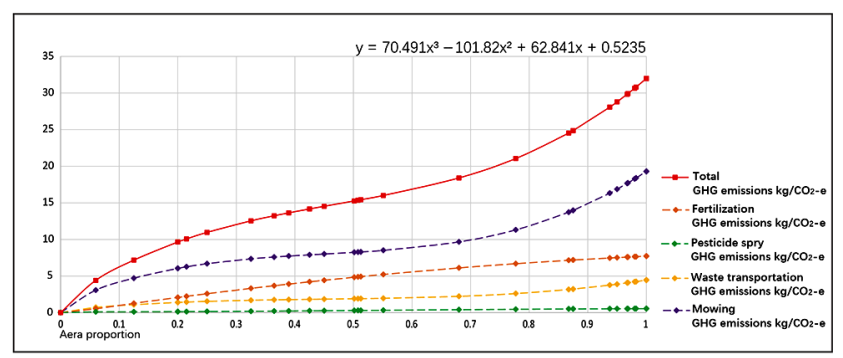

b)

Figure 11. The variation trends of maintenance energy consumption \& GHG emissions in the grassland layer of the sample plots

increased until reaching a maximum and then decreased as the tree density continued to increase and (b) an increasing curve with two peaks, where as the shrub, herbaceous, and grassland area proportions (X-axis) increased, the energy consumption or GHG emissions (Y-axis) increased dramatically in the beginning, then changed to a slower increase, and then finally changed back to rapid growth.

To analyse the trends in variation by plant layers in the maintenance of the woodland layer, the maximum energy consumption was present in the section with a plant density of 0.14 tree $/ \mathrm{m}^{2}-0.21$ tree $/ \mathrm{m}^{2}$, in which the energy cost was from $888 \mathrm{MJ} / \mathrm{y}^{-1}$ to approximately $930 \mathrm{MJ} / \mathrm{y}^{-1}$ in the sample plot size. The maximum GHG emissions of the woodland layer maintenance occurred when the plant density was from 0.11 tree $/ \mathrm{m}^{2}-0.15$ tree $/ \mathrm{m}^{2}$, which had GHG emissions from $8.5 \mathrm{~kg} / \mathrm{CO}_{2}$-e $/ \mathrm{y}^{-1}$ to approximately $8.9 \mathrm{~kg} / \mathrm{CO}_{2}-\mathrm{e} / \mathrm{y}^{-1}$. In the maintenance of the shrub layer, in terms of both its energy consumption and GHG emissions, there was no substantial increase in rate between their first peak and the area of stable increase. However, the maximum growth of in energy consumption and GHG values in the shrub layer both appeared after the area proportion reached 0.6 , where the energy consumption was approximately $805 \mathrm{MJ} / \mathrm{y}^{-1}$ and the GHG emissions were $13.8 \mathrm{~kg} / \mathrm{CO}_{2}-\mathrm{e} / \mathrm{y}^{-1}$ in the sample plot size. In the herbaceous layer, the energy consumption and GHG emission curves at the sample plot size showed their first significant increase when the proportion of the area was from 0 to 0.3 , where the energy consumption and GHG emissions were approximately $400 \mathrm{MJ} / \mathrm{y}^{-1}$ and $2.5 \mathrm{~kg} / \mathrm{CO}_{2}-\mathrm{e} / \mathrm{y}^{-1}$, respectively. Their second rapid increase started when the area proportion was 0.63 , where the energy consumption and GHG emissions were approximately $703 \mathrm{MJ} / \mathrm{y}^{-1}$ and $3.2 \mathrm{~kg} / \mathrm{CO}_{2}-\mathrm{e} / \mathrm{y}^{-1}$, respectively. In the grassland maintenance at the sample plot size, the slow increase in energy consumption and GHG emissions started when the area proportion was 0.38 0.68 , where its energy consumption was approximately $1100 \mathrm{MJ} / \mathrm{y}^{-1}-1600 \mathrm{MJ} / \mathrm{y}^{-1}$ and its GHG emissions were approximately $13.6 \mathrm{~kg} / \mathrm{CO}_{2}-\mathrm{e} / \mathrm{y}^{-1}-18.4 \mathrm{~kg} / \mathrm{CO}_{2}-\mathrm{e} / \mathrm{y}^{-1}$. When the grassland area proportions were $0-0.38$ and $0.68-1$, their maintenance energy costs and GHG discharge were rapidly increasing.

\section{Discussion}

\subsection{Differences in the energy consumption and GHG emissions due to the maintenance of a variety of multi-structure plant communities}

The types of maintenance work and workload differences with different plant structure combinations can cause differences in maintenance energy input and waste output in plant communities (Hitchmough \& Fieldhouse, 2008). The general view in urban ecological research notes that woodland has minimum maintenance requirements, while it provides maximum eco-benefits to the urban environment (Nowak \& Crane, 2002). Urban trees and forests affect air quality through the direct removal of air pollutants, altering local microclimates and building energy use, carbon sequestration, and providing aesthetic beauty to the urban landscape (Nowak, Hirabayashi, Doyle, McGovern, \& Pasher, 2018). According to Nowak's research, Trees and forests in the conterminous United States removed 17.4 million tonnes (t) of air pollution in 2010 with human health effects valued at $\$ 6.8$ billion, while most of the health impacts and values were within urban area (Nowak, Hirabayashi, Bodine, \& Greenfield, 2014). In contrast, grassland requires the largest maintenance workload in the urban greenspace, and it is also a significant contributor to maintenance energy consumption and GHG emissions (Jo \& McPherson, 1995). The results of this study can generally verify the above viewpoint. For maintenance at the sample plot size in an urban greenspace, the maximum energy cost and GHG discharge in the woodland layer were approximately $923 \mathrm{MJ} / \mathrm{y}^{-1}$ (density $=0.20$ ) and $8.70 \mathrm{~kg} / \mathrm{CO}_{2}-\mathrm{e} / \mathrm{y}^{-1}$ (density $=0.16$ ), respectively, which were only $34 \%$ and $27 \%$ of the corresponding values for the grassland layer (energy consumption was $2734 \mathrm{MJ} / \mathrm{y}^{-1}$ and GHG emissions were $32 \mathrm{~kg} / \mathrm{CO}_{2}-\mathrm{e} / \mathrm{y}^{-1}$ when the proportion of the area was 1). However, the GHG variation curves for grassland and shrubs intersected when their proportions of the total area reached 0.9 , and the curve for shrubs overtook grassland with the continued growth of their area proportions, finally achieving $34.8 \mathrm{~kg} / \mathrm{CO}_{2}-\mathrm{e} / \mathrm{y}^{-1}$ (area proportion $=1$ ).

In a multi-structure plant community, the shrub layer, herbaceous layer and the grassland layer together cover the ground of the greenspace. In comparing the energy 
consumption and GHG emissions of these three layers at the same area proportions, the herbaceous layer has the clear advantage in terms of saving maintenance energy and reducing GHG emissions. In the study area, the average annual maintenance energy consumption per $\mathrm{m}^{2}$ and GHG emissions in the herbaceous layer was only $31 \%$ and $22 \%$ those of grassland.

According to our study, it is obviously possible to reduce the maintenance energy cost and the GHG emissions if the majority of the ground in an urban greenspace is covered by an herbaceous layer and with some trees planted, but reducing the environmental influence of greenspace maintenance is not the only consideration in establishing the urban greenspace. As a multi-functional area, the urban greenspace has to consider satisfying usable functionality for the urban users (Bo, Adimo, \& Bao, 2009), offering landscape visualization to the urban citizens (Hitchmough \& Fieldhouse, 2008) and creating a biodiverse environment for the urban ecology (Dunnett \& Hitchmough, 2004). On the other hand, the multiplant layers greenspace (semi-natural and artificial) can increase the overall vegetation cover, thus contributing to conservation of biological diversity in urban area (Tzoulas et al., 2007). Loreau points out a commonly hypothesized that species-rich communities are more resistant to invasion than species-poor communities, because they use the available resources more efficiently (Loreau et al., 2002). Furthermore, as a major part of urban green infrastructure, the species richness greenspace may have a considerable potential for improving the well-being and health of urban residents (Tzoulas et al., 2007). That means on most occasions a single plant structure is unable to meet the functional demands of the urban greenspace. To find a reasonable plant structure combination model that can achieve the function requirement while having low maintenance environmental impact, it is necessary to discuss the maintenance energy consumed and GHGs discharged in dynamic variations of plant structures in an urban greenspace design.

\subsection{Prediction of the levels of maintenance energy consumption and GHG emissions in plant structure combinations in urban greenspace}

Structurally complex plant communities can be regarded as naturistic greenspace models and can deliver more eco-benefit to the urban environment than a single plant layer area (Tooker \& Hanks, 2000). Based on the variation characteristics of the energy consumption and the GHG emission curves in the different plant layers, we summarized the specific plant structure types to indicate the low, average and the high energy consumption and GHG emission ranges in multi-structure urban greenspace maintenance.

In urban greenspace design, it is necessary to spread the site with plant materials on most occasions (Semenzato, Sievänen, de Oliveira, Soares, \& Spaeth, 2011). First, dividing the area into the grassland, herbaceous and shrub layers, each with an area proportion of 0.33 , and planting trees at a density of 0.024 tree/ $\mathrm{m}^{2}$ can achieve the maximum boundary of low energy consumption and GHG emissions section (structure combination shown in Figure 12). Then, decreasing the grassland area, reducing the tree density and increasing the proportions of the herbaceous and shrub layers can provide relatively low maintenance energy costs and GHG emissions (Table 6, Figure 12). Additionally, the maximum boundaries of average maintenance energy costs and GHG emissions are achieved by increasing the grassland area proportion to 0.68 , maintaining the shrub layer proportion at 0.32 , decreasing the herbaceous layer proportion to 0 , and increasing the tree density to 0.06 (Table 6, structure combination shown in Figure 13). Furthermore, the maximum boundary of the high maintenance energy consumption appears when the grassland area proportion reaches 1 and the tree density is 0.2 , which is a double plant layer greenspace of combined forest and grassland (Table 6, structure combination shown in Figure 14). Finally, the forest and shrub greenspace (shrub AP $=1$, tree $\mathrm{D}=0.14$ ) leads to maximum GHG emissions within the high maintenance energy and the GHG emissions section (Table 6, structure combination shown in Figure 15). At present, the construction of a more natural urban greenspace with fewer maintenance requirements and low environmental impact is the common pursuit of city managers and landscape designers (Shu-Hua, 2010). The maintenance energy consumption and GHG emission predictions for multi-structure plant communities can help to decrease the environmental impact of maintenance by adjusting the plant structure combination in the design of future urban greenspace.

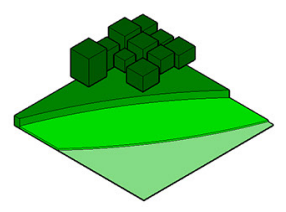

Structure combination

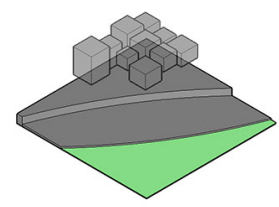

Grassland layer $\left(\mathrm{AP}^{\star} 1=0-0.33\right)$

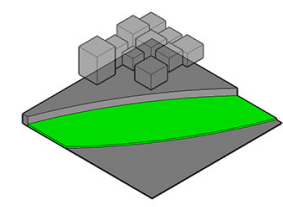

Herbaceous layer $\left(\mathrm{AP}^{\star} 1=0-1\right)$



Shrubs layer $\left(\mathrm{AP}^{\star} 1=0-0.6\right)$

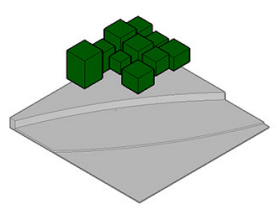

Woodland layer $\left(D^{\star} 2=0-0.024\right)$

Note ${ }^{\star} 1$ - Area proportion; ${ }^{\star} 2-$ Density $\left(\right.$ tree $\left./ \mathrm{m}^{2}\right)$.

Figure 12. The plant combination with the low energy consumption and GHG emissions due to annual maintenance 
Table 6. The low, average and high levels of maintenance energy consumption and GHG emissions in the various plant combinations

\begin{tabular}{|c|c|c|c|c|c|c|c|c|c|c|c|}
\hline \multirow{2}{*}{$\begin{array}{c}\text { Energy \& } \\
\text { GHG } \\
\text { condition }\end{array}$} & \multicolumn{2}{|c|}{$\begin{array}{c}\text { Woodland layer } \\
\text { plant density } \\
\text { tree } / \mathrm{m}^{2}\end{array}$} & \multicolumn{2}{|c|}{$\begin{array}{c}\text { Shrubs layer area } \\
\text { proportion }\end{array}$} & \multicolumn{2}{|c|}{$\begin{array}{l}\text { Herbaceous layer } \\
\text { area proportion }\end{array}$} & \multicolumn{2}{|c|}{$\begin{array}{l}\text { Grassland layer } \\
\text { area proportion }\end{array}$} & \multirow{2}{*}{$\begin{array}{c}\text { Energy } \\
\text { con- } \\
\text { sump- } \\
\text { tion MJ/ } \\
\mathrm{m}^{2} / \mathrm{y}^{-1} \\
\mathrm{Max}^{* 2}\end{array}$} & \multirow{2}{*}{$\begin{array}{c}\text { GHG } \\
\text { emission } \\
\text { kg/ } \\
\mathrm{CO}_{2} \text {-e/ } \\
\mathrm{m}^{2} / \mathrm{y}^{-1} \\
\mathrm{Max}^{\star 2}\end{array}$} & \multirow[t]{2}{*}{$\begin{array}{l}\text { Figure } \\
\text { reference }\end{array}$} \\
\hline & Range & $\operatorname{Max}^{* 1}$ & Range & $\operatorname{Max}^{* 1}$ & Range & $\operatorname{Max}^{* 1}$ & Range & $\operatorname{Max}^{* 1}$ & & & \\
\hline Low & $0-0.024$ & 0.024 & $0-0.6$ & 0.33 & $0-1$ & 0.33 & $0-0.33$ & 0.33 & 5.29 & 0.06 & Figure 12 \\
\hline Average & $0.025-0.06$ & 0.06 & $0.32-0.66$ & 0.32 & $0-0.66$ & 0 & $0.34-0.68$ & 0.68 & 6.36 & 0.08 & Figure 13 \\
\hline $\begin{array}{l}\text { High Energy } \\
\text { consumption }\end{array}$ & $0.061-0.23$ & 0.2 & $0-0.31$ & 0 & $0-0.31$ & 0 & $0.69-1$ & 1 & 9.14 & - & Figure 14 \\
\hline $\begin{array}{l}\text { High } \\
\text { GHG emission }\end{array}$ & $0.061-0.23$ & 0.14 & $0.9-1$ & 1 & $0-0.1$ & 0 & $0-0.1$ & 0 & - & 0.1 & Figure 15 \\
\hline
\end{tabular}

Note: ${ }^{* 1}$ - The maximum point of the tree density and the shrubs/herbaceous/grassland area proportion for the low/average/high annual maintenance energy consumption and GHG emission; ${ }^{\star 2}$ - The maximum energy consumption and GHG emission values in the plant combination of the low/average/high annual maintenance energy consumption and GHG emissions.

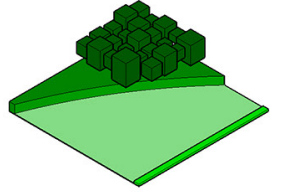

Structure combination

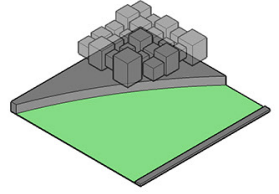

Grassland layer $\left(\mathrm{AP}^{\star} 1=0-0.1\right)$

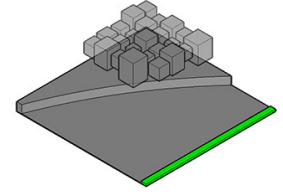

Herbaceous layer $\left(\mathrm{AP}^{\star} 1=0-0.1\right)$

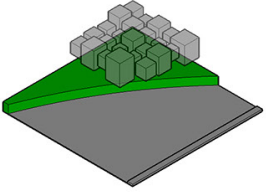

Shrubs layer $\left(\mathrm{AP}^{\star} 1=0.9-1\right)$

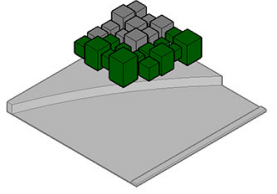

Woodland layer $\left(\mathrm{D}^{\star} 2=0.61-0.23\right)$

Note: ${ }^{\star} 1$ - Area proportion; ${ }^{\star} 2$ - Density $\left(\right.$ tree $\left./ \mathrm{m}^{2}\right)$.

Figure 13. The plant combination with average energy consumption and GHG emissions due to annual maintenance

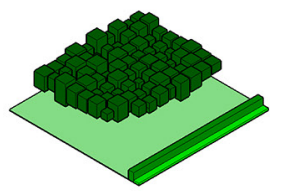

Structure combination

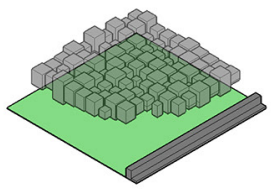

Grassland layer $\left(\mathrm{AP}^{\star} 1=0.34-0.68\right)$

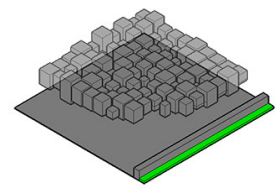

Herbaceous layer $\left(\mathrm{AP}^{\star} 1=0-0.66\right)$

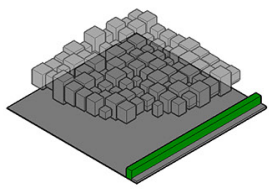

Shrubs layer $\left(\mathrm{AP}^{\star} 1=0.32-0.66\right)$

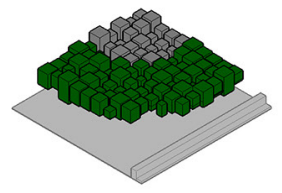

Woodland layer $\left(D^{\star} 2=0.025-0.06\right)$

Note: ${ }^{\star} 1$ - Area proportion; ${ }^{\star} 2-$ Density $\left(\right.$ tree $\left./ \mathrm{m}^{2}\right)$.

Figure 14. The plant combination with the high energy consumption due to annual maintenance

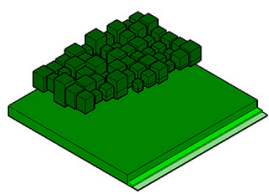

Structure combination

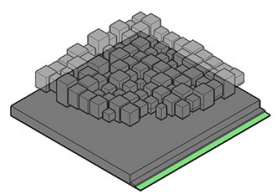

Grassland layer $\left(\mathrm{AP}^{\star} 1=0.69-1\right)$

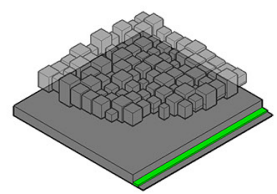

Herbaceous layer $\left(\mathrm{AP}^{\star} 1=0-0.31\right)$

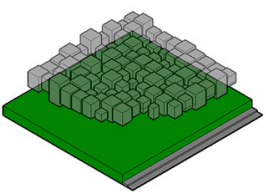

Shrubs layer $\left(\mathrm{AP}^{\star} 1=0-0.31\right)$



Woodland layer $\left(D^{\star} 2=0.61-0.23\right)$

Note: ${ }^{\star} 1$ - Area proportion; ${ }^{\star} 2-$ Density $\left(\right.$ tree $\left./ \mathrm{m}^{2}\right)$.

Figure 15. The plant combination with the high GHG emissions due to annual maintenance 


\section{Conclusions}

The conclusions drawn from this annual maintenance energy consumption and GHG emission study in the urban greenspace in Zheng Zhou, China are as follows:

1. Changes in the annual maintenance work types and workload have a strong relationship with changes in the plant structure combinations (the density of trees and the shrub, herbaceous, and grassland area proportions) in urban greenspace, and maintenance work can directly cause energy consumption and GHG emissions.

2. In woodland, shrub, and herbaceous maintenance, the largest contributor to energy consumption was irrigation, while the largest contributor to GHG emissions was fertilization. Grass mowing in grassland maintenance was the largest single contributor to both energy costs and GHG discharge.

3. In the annual maintenance of the woodland layer, increased plant density led to first an increase and then a decrease in energy costs and GHG emissions. The plots of variations in energy use and GHG emissions in woodlands had parabolic trends. Annual variations in maintenance energy use and GHG emissions in the shrub, herbaceous, and grassland layers were increasing curves with double peaks. In general, variation in maintenance energy consumption and GHG emissions increased as the plant area proportions increased, but with a plateau in the middle section of the area proportion.

4. In the annual maintenance of multi-structure urban greenspace, there were low, average and high levels of energy consumption and GHG emissions that can be divided according to the change in the structure combinations (the density of trees and the shrub, herbaceous, and grassland proportions). This relationship can be referenced to understand the environmental impacts of existing and future urban greenspace.

The basic function of the greenspace is providing maximum ecosystem services to the residents. The original goal of the plant maintenance work is to "assist" to deliver the eco-services function in a better way, but it increased the environmental burden simultaneously. Our research can help to understand the data changing of the maintenance energy consumption and GHG emissions through the change of plant structure combinations in urban greenspaces. To considering this result, the future urban greenspace can be designed in better plant structures to limit the maintenance environmental impacts, thus to improve the ecosystem service and well-being values to urban residents.

\section{References}

Barker, A. V., \& Prostak, R. G. (2009). Alternative management of roadside vegetation. HortTechnology, 19(2), 346-352.

Berg, S., \& Lindholm, E. L. (2005). Energy use and environmental impacts of forest operations in Sweden. Journal of Cleaner Production, 13(1), 33-42.

https://doi.org/10.1016/j.jclepro.2003.09.015
Bixler, R. D., \& Floyd, M. F. (1997). Nature is scary, disgusting and uncomfortable. Environment \& Behavior, 29(4), 443-467. https://doi.org/10.1177/001391659702900401

Bo, C., Adimo, O. A., \& Bao, Z. (2009). Assessment of aesthetic quality and multiple functions of urban green space from the users' perspective: the case of Hangzhou Flower Garden, China. Landscape and Urban Planning, 93(1), 76-82. https://doi.org/10.1016/j.landurbplan.2009.06.001

Casey, J. W., \& Holden, N. M. (2006a). Greenhouse gas emissions from conventional, agri-environmental scheme, and organic Irish suckler-beef units. Journal of Environmental Quality, 35(1), 231-239. https://doi.org/10.2134/jeq2005.0121

Casey, J. W., \& Holden, N. M. (2006b). Quantification of GHG emissions from sucker-beef production in Ireland. Agricultural Systems, 90(1), 79-98.

https://doi.org/10.1016/j.agsy.2005.11.008

Dunnett, N., \& Hitchmough, J. (2004). The dynamic landscape: design, ecology and management of naturalistic urban planting. New York: Taylor \& Francis. https://doi.org/10.4324/9780203402870

Fuglestvedt, J. S. (2010). Policy Update: multicomponent climate policy: why do emission metrics matter? Carbon Management, 1(2), 191-197. https://doi.org/10.4155/cmt.10.28

Gu, D. N., Li, L. P., Xing, W. Q., \& Zhao, C. (2009). Distribution of heavy metals in urban soils of Zhengzhou City and soil quality assessment. Chinese Journal of Soil Science, 40, 921-925.

Haas, G., Wetterich, F., \& Köpke, U. (2001). Comparing intensive, extensified and organic grassland farming in southern Germany by process life cycle assessment. Agriculture, Ecosystems \& Environment, 83(1), 43-53. https://doi.org/10.1016/S0167-8809(00)00160-2

Hitchmough, J., \& Fieldhouse, K. (2008). Plant user handbook: a guide to effective specifying. UK: Wiley.

Ingram, D. L. (2012). Life cycle assessment of a field-grown red maple tree to estimate its carbon footprint components. The International Journal of Life Cycle Assessment, 17(4), 453-462. https://doi.org/10.1007/s11367-012-0398-7

International Organization for Standardization. (2006). Environmental management - Life cycle assessment - Principles and framework (ISO 14040). Retrieved from https://www.iso.org/ standard/37456.html

Jiang, S. P., \& Peng, Y. L. (2003). Study on maintenance and management for residential planting. Journal of Chinese Landscape Architecture, 3, 1-8.

Jo, H. K. (2002). Impacts of urban greenspace on offsetting carbon emissions for middle Korea. Journal of Environmental Management, 64(2), 115-126.

https://doi.org/10.1006/jema.2001.0491

Jo, H. K., \& McPherson, G. E. (1995). Carbon storage and flux in urban residential greenspace. Journal of Environmental Management, 45(2), 109-133.

https://doi.org/10.1006/jema.1995.0062

Khan, M. Y., Russell, R. L., Welch, W. A., Cocker III, D. R., \& Ghosh, S. (2012). Impact of algae biofuel on in-use gaseous and particulate emissions from a marine vessel. Energy \& Fuels, 26(10), 6137-6143. https://doi.org/10.1021/ef300935z

Kuo, F. E., Bacaicoa, M., \& Sullivan, W. C. (1998). Transforming inner city landscapes: trees, sense of place and preference. Environment \& Behavior, 30(1), 28-59. https://doi.org/10.1177/0013916598301002

Lazzerini, G., Lucchetti, S., \& Nicese, F. P. (2015). Green House Gases(GHG) emissions from the ornamental plant nursery 
industry: a Life Cycle Assessment(LCA) approach in a nursery district in central Italy. Journal of Cleaner Production, 112(Part 5), 4022-4030.

Laiyun, S., Wenbo, W., \& Weisheng, Z. (2015). China statistical yearbook. Beijing: China Statistics Press.

Lindholst, A. C. (2008). Improving contract design and management for urban green-space maintenance through action research. Urban Forestry \& Urban Greening, 7(2), 77-91. https://doi.org/10.1016/j.ufug.2008.02.001

Loreau, M., Downing, A., Emmerson, M., Gonzalez, A., Hughes, J., Inchausti, P., Joshi, J., Norberg, J., \& Sala, O. (2002). A new look at the relationship between diversity and stability. In M. Lorea, S. Naeem, \& P. Inchausti (Eds.), Biodiversity and ecosystem functioning. Oxford: Oxford University Press.

Management Committee of Zheng Dong New District. (2017). Environment and ecological. Retrieved from http://www.zhengdong.gov.cn/sitesources/zhengdong/page_pc/qq/sthj/list1.html/

Mobtaker, H. G., Keyhani, A., Mohammadi, A., Rafiee, S., \& Akram, A. (2010). Sensitivity analysis of energy inputs for barley production in Hamedan Province of Iran. Agriculture, Ecosystems \& Environment, 137(3), 367-372. https://doi.org/10.1016/j.agee.2010.03.011

Mohammadshirazi, A., Akram, A., Rafiee, S., Avval, S. H. M., \& Kalhor, E. B. (2012). An analysis of energy use and relation between energy inputs and yield in tangerine production. Renewable and Sustainable Energy Reviews, 16(7), 4515-4521. https://doi.org/10.1016/j.rser.2012.04.047

National Geomatics Center of China. (2017). Map Word He Nan. Beijing: National Geomatics Center of China.

Nowak, D. J., \& Crane, D. E. (2002). Carbon storage and sequestration by urban trees in the USA. Environmental Pollution, 116(3), 381-389. https://doi.org/10.1016/S0269-7491(01)00214-7

Nowak, D. J., Hirabayashi, S., Bodine, A., \& Greenfield, E. (2014). Tree and forest effects on air quality and human health in the United State. Environmental Pollution, 193(4), 119-129. https://doi.org/10.1016/j.envpol.2014.05.028

Nowak, D. J., Hirabayashi, S., Doyle, M., McGovern, M., \& Pasher, J. (2018). Air pollution removal by urban forests in Canada and its effect on air quality and human health. Urban Forestry \& Urban Greening, 29, 40-48. https://doi.org/10.1016/j.ufug.2017.10.019

Rafiee, S., Mousavi Avval, S. H., \& Mohammadi, A. (2010). Modeling and sensitivity analysis of energy inputs for apple production in Iran. Energy, 35(8), 3301-3306. https://doi.org/10.1016/j.energy.2010.04.015

Semenzato, P., Sievänen, T., de Oliveira, E. S., Soares, A. L., \& Spaeth, R. (2011). Natural elements and physical activity in urban green space planning and design. In K. Nilsson, M. Sangster, C. Gallis, T. Hartig, S. De Vries, K. Seeland, \& J. Schipperijn (Eds.), Forests, trees and human health (pp. 245282). Dordrecht: Springer. https://doi.org/10.1007/978-90-481-9806-1_9

Shu-Hua, L. (2010). Symbiosis and circulation-the basic thought of urban green space construction under low-carbon economic society. Chinese Landscape Architecture, 6, 014.

Singh, S., \& Mittal, J. P. (1992). Energy in production agriculture. Delhi: Mittal Publications.
Standardization Administration of the People's Republic of China. (2008). Reciprocating internal combustion enginesperformance-part 1: declarations of power, fuel and lubricating oil consumption and test methods-additional requirements for engines for general use. Bei Jing: Standards Press of China. Standardization Administration of the People's Republic of China. (2011). Reciprocating internal combustion engines-exhaust emission measurement-part 2: measurement of gaseous and particulate exhaust emissions at site. Bei Jing: Standards Press of China.

Tooker, J. F., \& Hanks, L. M. (2000). Influence of plant community structure on natural enemies of pine needle scale (Homoptera: Diaspididae) in urban landscapes. Environmental Entomology, 29(6), 1305-1311.

https://doi.org/10.1603/0046-225X-29.6.1305

Tzoulas, K., Korpela, K., Venn, S., Yli-Pelkonen, V., Kaźmierczak, A., Niemela, J., \& James, P. (2007). Promoting ecosystem and human health in urban areas using Green Infrastructure: A literature review. Landscape and Urban Planning, 81(3), 167178. https://doi.org/10.1016/j.landurbplan.2007.02.001

Wang, X., Wu, Q., Zhou, J., Chen, Y., \& Wu, F. (2014). Life cycle assessment of tomato production in greenhouses. Acta Scientiae Circumstantiae, 34(11), 2940-2947.

Wang, X. D., Yang, Q. S., \& Zhang, Q. F. (2016). Research on the construction of landscape plant communities and management in the urban green space. Chinese Landscape Architecture, 1, 1-16.

West, T. O., \& Marland, G. (2002). A synthesis of carbon sequestration, carbon emissions, and net carbon flux in agriculture: comparing tillage practices in the United States. Agriculture, Ecosystems \& Environment, 91(1), 217-232. https://doi.org/10.1016/S0167-8809(01)00233-X

Xiao-Yu, P., Xi-Hui, W., Fa-Qi, W., Xiao-Qin, W., \& Xiao-Gang, T. (2015). Life cycle assessment of winter wheat-summer maize rotation system in Guanzhong region of Shaanxi province. Journal of Agro-Environment Science, 4, 809-816.

Yadav, R. (2014). Handbook of agricultural engineering. International Journal of Industrial Ergonomics, 44(6), 894-895. https://doi.org/10.1016/j.ergon.2014.09.008

Yang, L., Zhi, C., Tingning, W., \& Shuibao, L. (2015). Study on greenhouse gas emission of nitrogen based on life cycle assessment. Environment and Sustainable Development, 40(3), 66-68.

Yongchang, S. (2001). Vegetation ecology (2th ed.). Bei Jing: East China Normal University Press.

Yuan-Yuan, J. I. (2015). Research of the evaluation system and strategies of low carbon landscape based on the sustainable development idea. Tian Jin: Tian Jin University.

Yuan-Yuan, J. I., Genovese, P. V., University, T. A., \& University, T. (2016). Research on the carbon emission from the daily use and maintenance on the basis of life cycle of landscape architecture. Landscape Architecture, 9, 121-126.

Zheng Zhou Meteorological Bureau. (2018). Remote sensing information of agricultural meteorological in Zheng Zhou. Retrieved from http://www.zhengdong.gov.cn/sitesources/ zhengdong/page_pc/qq/sthj/list1.html/ 